\title{
Conservation of adaptive potential and functional diversity: integrating old and new approaches
}

\author{
Barbara K. Mable ${ }^{1} \mathbb{D}$
}

Received: 26 April 2018 / Accepted: 20 November 2018 / Published online: 3 December 2018

(c) The Author(s) 2018

\begin{abstract}
Continuing advances in whole genome scale approaches integrated with other 'omic' technologies promise to revolutionise understanding about the relevance of genetic variation to risks of species declines and extinctions. In the face of the vastly increased accessibility of such approaches, it is important that we advance beyond descriptive genetics to developing a more functional perspective on whether enhancing genetic variation is the most effective strategy for conservation management. Rather than a comprehensive review of the field, this paper focuses on several key issues that have been discussed since the dawn of "conservation genetics" and that warrant re-assessment based on emerging "omics" data, combined with new analytical approaches to ecological niche modelling and population genomic analyses. Specifically, the following inter-related issues are discussed: (1) the relative impacts of inbreeding and outbreeding on fitness and adaptive potential, particularly in relation to genetic rescue; (2) how "species" should be defined for conservation management; (3) deciding on how much and what type of genetic variation should be preserved; and (4) how we can move from descriptive genetics to actually understanding adaptive processes in the wild. None of the ideas presented are new; the purpose here is to serve as a reminder that many of the issues raised 30 years ago are still relevant but not completely resolved and would benefit from tackling afresh with modern tools, but considering historical perspectives.
\end{abstract}

Keywords Conservation genetics · Adaptive potential $\cdot$ Population genomics $\cdot$ Inbreeding $\cdot$ Species concepts $\cdot$ Genetic rescue

\section{Introduction}

As evident from the papers presented in this special issue, it is an exciting time to be a conservation geneticist. Continuing advances in sequencing technologies and analytical pipelines means that we are on the brink of a step change in understanding the functional role that genetic variation plays in adaptation to changing environments. Population geneticists and systematists have always been at the forefront of exploiting new developments, often using new technologies to test much older theories. Integrating molecular genetics into conservation began with allozymes in the 1970s, followed in the 1980s by DNA sequences and restriction fragment length polymorphisms based on high copy number

Barbara K. Mable

Barbara.mable@glasgow.ac.uk

1 Institute of Biodiversity, Animal Health and Comparative Medicine (IBAHCM), University of Glasgow, Graham Kerr Building, University Avenue, Glasgow G12 8QQ, UK molecules such as mitochondria (mtDNA) and ribosomes (rDNA). However, it was automation of the polymerase chain reaction (PCR) made possible by use of a thermostable polymerase in the late 1980s (Mullis and Faloona 1987; Saiki et al. 1988) that really revolutionised accessibility and affordability of DNA sequencing and fragment analyses to inform conservation decisions across a wide range of species.

In the midst of the current "omics" revolution, it is worthwhile revisiting perspectives from the brink of this PCR revolution (Lande 1988; O'Brien and Evermann 1988; Ralls et al. 1988; Simberloff 1988; Avise 1989). What is striking is that, despite a monumental increase in knowledge about patterns of genetic variation across a wide range of captive and wild populations, many of the same fundamental issues are still under debate. Avise (1989) envisioned that: "As increasingly sophisticated methods of descriptive molecular genetics are applied to natural populations (or as more DNA sequence data become available), opportunities for finer distinctions will result, and in the extreme, virtually 
every local population, family unit, and even individual may prove distinguishable from all others by some recently derived genetic trait." However, while he promoted the use of sequence data to identify genetically unique populations or cryptic species (e.g. defining Evolutionarily Significant Units, or ESUs: Ryder 1986; Moritz 1994b) he was against using only molecular data to make management decisions. Lande (1988) argued that demographic and behavioural considerations would have more immediate consequences for population declines than genetics; individuals in many species show decreased reproduction at low population densities for non-genetic reasons, such as restricted mate availability (i.e. the Allee effect: reviewed in Avise 1989). Similarly, in response to arguments that loss of genetic variation and inbreeding depression could seriously increase extinction risk in highly endangered species like cheetahs (O'Brien 1994), field ecologists made a plea that genetics should not replace detailed ecological assessments of drivers of population declines because factors such as predation, poaching or habitat loss would result in more immediate effects than slower genetic declines (Caro and Laurenson 1994). Simberloff (1988) comprehensively reviewed the contribution of population and community biology to the field of conservation and emphasised that populations are threatened not only by genetics, demography, and environmental stochasticity but also by behavioural and physiological effects. Thus, even 30 years ago, there was concern that as molecular variation became an arguably easier quantity to measure than ecological factors, there was a risk that descriptive genetics would replace detailed assessments of other drivers of population declines.

Frankham (2010) reiterated this concern as whole genome approaches started to be applied to non-model organisms: "It is to be hoped that genomic tools will be wisely used to address important issues in conservation genetics, rather than becoming a bandwagon with a substantial proportion of trivial work, as happened subsequent to the introduction of allozymes." What the "omics" revolution offers is a real opportunity to shift from cataloguing patterns of variation at a finer scale across even more organisms to combining different techniques to fully understand adaptive processes that might be compromised by anthropogenic or natural habitat changes.

The purpose of this paper is to highlight ongoing conservation-related debates where we now have the potential to make real progress in directly relating genetic variation at the scale of whole genomes to phenotypic, fitness, and ecological consequences and using this information to make predictions about adaptive potential in changing environments. Rather than a comprehensive review, the aim is to focus on some recurring issues, both from historical perspectives and using some recent examples to highlight how genome-scale approaches are starting to contribute to altered understanding. The ultimate objective is to promote discussion of what we still don't know and how we might fill those gaps in knowledge, to ensure that the powerful set of tools now at our disposal are used most effectively to inform conservation management decisions.

\section{Consequences of inbreeding}

Even before it was practical to use genetic markers to quantify variation in natural populations, there has been concern that human-mediated changes in habitat availability would increase risk of extinction of threatened populations by reducing effective population size and increasing rates of inbreeding. Despite critical discussion of these issues for the past 30 years, remarkably little consensus still persists today. Franklin and Frankham (1998) discussed the difficulty of establishing and making generalisations about how large populations must be to retain evolutionary potential, and the concept of a minimum viable effective population size (Nunney and Campbell 1993) and how this relates to heritability and selection (Wood et al. 2016) and the adaptive potential of small populations (Willi et al. 2006) has long been discussed. Avise (1989) pointed out that there is extensive variation among species in the fitness costs of inbreeding (Ralls et al. 1988) but that many species naturally have breeding systems (e.g. self-fertilisation or mating with siblings) or geographic population structures that reduce heterozygosity below what would be predicted under neutral expectations for high outcrossing and unrestricted gene flow. In such circumstances, purging of negative deleterious mutations in highly inbred individuals could alter the fitness consequences of increased habitat fragmentation and reductions in population size. However, the rate and effectiveness of purging the genetic load without an increase in extinction is dependent on the genetic basis of inbreeding depression (Charlesworth and Charlesworth 1999), which is not known for many species (Hedrick 1994). Keller and Waller (2002) predicted that purging should be strongest for slightly inbred plants with restricted gene flow. This could explain lack of strong fitness differences between populations of the plant Arabidopsis lyrata that have recently undergone a shift to inbreeding compared to their outcrossing sibling populations (Stift et al. 2013; Carleial et al. 2017), despite substantial loss of heterozygosity and diversity across the genome (Foxe et al. 2010; Buckley et al. 2018). Heterozygosity-fitness correlations have long been used to investigate the consequences of inbreeding in wild populations (David 1998) but strong correlations are sometimes restricted to a few traits that arguably could reduce competitiveness (e.g. traits related to growth in white-tailed deer: Brommer et al. 2015; and steelhead trout: Naish et al. 2013), rather than drive population-level extinctions. Persistence and divergence 
in parts of the genome associated with adaptive processes, despite the presence of detrimental anatomical and physiological effects associated with inbreeding (e.g. in brown bears: Benazzo et al. 2017), also suggests that genetic load should be considered in relation to important functional loci rather than global patterns of heterozygosity.

Thirty years ago, Simberloff (1988) and Lande (1988) questioned the effects of inbreeding and loss of genetic diversity as a major factor affecting the persistence of populations in the wild. While inbreeding and loss of heterozygosity results in individual fitness costs, what they thought was lacking were concrete demonstrations that inbreeding caused any wild populations to decline; connections between heterozygosity and population viability are complex and hard to predict a priori. In contrast, although recognising that most information at the time was based on laboratory experiments and domesticated populations, Lacy (1997) suggested that, even in the wild, no species of mammal had been shown to be unaffected by inbreeding and that there was no evidence for effective purging. On the surface this might seem to be a dichotomous debate between mammal and plant-centric viewpoints. However, actual evidence to test whether reduced heterozygosity and genetic diversity of inbred individuals increases risks of extinction at the population level (Newman and Pilson 1997) and the functional implications of heterozygosity-fitness correlations (David 1998) have been somewhat limited by the focus on highly variable but neutral genetic markers (Ouborg et al. 2010). A major contribution emerging from genome-scale analyses is the identification of particular loci associated with inbreeding depression, rather than focusing on overall heterozygosity (e.g. Steiner et al. 2013). Classic examples of long-term persistence despite extremely low levels of genome-wide variation (e.g. Island foxes: Robinson et al. 2016) questions the dogma that lack of overall genetic variation will mean inevitable extinction and suggests that assessing variation at loci associated with adaptation could be more informative. Inferring an extinction to be attributed to inbreeding based on low genome-wide heterozygosity of the few remaining individuals in a population (e.g. the Sierra Morena wolf population: Gómez-Sánchez et al. 2018) also risks confounding factors originally causing the loss of genetic variation with those resulting in low population viability. Thus, even based on more recent genomic evidence, disentangling whether loss of genetic diversity per se, inbreeding depression, or other factors associated with population declines or habitat fragmentation drive extinction (Ouborg et al. 2010) remains a challenge.

Nevertheless, for species perceived to be at high risk of extinction through genetic erosion, "genetic rescue" by augmenting populations from captively bred sources or translocations between isolated populations (Storfer 1999; Weeks et al. 2011) has frequently been suggested. However, opponents have questioned the relative value of alleviating the negative effects of inbreeding depression and inducing beneficial effects of heterosis through genetic supplementation compared to potentially unknown consequences of outbreeding depression (Edmands 1999). Mating between dissimilar individuals, while increasing genetic variation in the resulting progeny, can disrupt favourable gene combinations and reduce fitness under some circumstances (Templeton 1986; Avise 1989). For plants with limited dispersal, for example, an intermediate genetic distance has been suggested to be optimal for outcrossing, due to local adaptation (Price and Waser 1979). It is also important to distinguish between short-term benefits and increases in long-term adaptive potential (Lynch and O'Hely 2001). Even if shortterm local adaptation is reduced, the benefits of supplementation if only divergent immigrants are available could be preferable to doing nothing (Kronenberger et al. 2017) and it has been questioned whether outbreeding depression has been overestimated (Ralls et al. 2017). Frankham (2015) performed a meta-analysis demonstrating the success of genetic rescue across generations for the limited number of examples available but demonstrated consistent benefits of outcrossing for inbred populations in both stressful and benign environments. Establishing the genetic basis of inbreeding depression, heterosis and outbreeding depression from a genome-wide scale is now achievable but requires time consuming accompanying fitness studies performed under ecologically realistic conditions.

Common garden or laboratory experiments are powerful tools for quantifying the effects of inbreeding depression but have demonstrated the complexity of interpreting fitness consequences that could be generalised across species. Fitness can be context dependent, with the magnitude of inbreeding depression increasing under stressful conditions (e.g. Fox and Reed 2011) and differing between life history stages (e.g. Eckert and Barrett 1994). Variation in the genetic basis for inbreeding depression (Charlesworth and Charlesworth 1999), for example, could alter effects in natural populations. Despite demonstration of strong inbreeding depression, mixed mating appears to be a common and sustainable strategy in flowering plants (Goodwillie et al. 2005), which could reflect the dynamic nature of fitness consequences. Aguilar et al. (2008) suggested that shifts in mating systems (i.e. increased selfing) in plants are associated with habitat fragmentation; however, inbreeding depression is not always apparent in populations of normally outcrossing species with recent habitat-associated shifts in mating system (Carleial et al. 2017). Amos and Balmford (2001) commented that populations that have gone through a severe bottleneck can show a remarkable ability to respond to novel environmental changes. Frankham (1995) was concerned that despite the fundamental assumption underlying many conservation genetics strategies that inbreeding increases 
risks of extinction, there was a lack of information on the shape of the relationship or how to distinguish genetic from nongenetic effects. Experiments in Drosophila, for example, suggested that a threshold level of inbreeding could tip the balance toward extinction (Frankham 1995) but the shape of the curve changes upon exposure to stressors such as toxins and pathogens. More recently, common garden experiments combined with genomics in Drosophila (Schou et al. 2017) has revealed that the consequences of inbreeding might also vary across the genome: they explained a slower rate of loss of genetic diversity in small populations than theoretically expected by associative overdominance, with homozygosity of deleterious recessive alleles selected against in regions of low recombination. What is required are more studies like this that investigate the mechanisms underlying genetic diversity (Fraser 2017) rather than assuming that low levels of genetic diversity due to inbreeding mean inevitable extinction of small populations.

\section{Species concepts}

The incorporation of molecular markers into systematics (reviewed in Hillis et al. 1996) altered perspectives on species designations compared to morphological studies alone but how this should be used in conservation has been the subject of continuous debate. Based on discussions at a conference of the American Association of Zoological Parks and Aquariums (AAZPA), the concept of Evolutionarily Distinct Units (ESUs) for conservation was proposed as an alternative to the controversial exercise of naming subspecies (Ryder 1986). What has been debated subsequently is how to define what these units are and how they should be used for practical management (Moritz 1994b; Vogler and DeSalle 1994; Fraser and Bernatchez 2001). Even some of the original proponents of the idea emphasise that preserving habitats and focusing on ecological or evolutionary processes will ultimately be preferable to conservation of particular phenotypes or genotypes (Moritz 1999, 2002); process-oriented approaches, for example, might recommend restricting translocation of animals between ESUs but allow for mixing among Management Units (MSUs) within ESUs, to preserve adaptive potential (Moritz 2002). Focusing on evolutionary potential of ecosystems based on phylogenetic diversity in hotspots rather than individual species is also worthy of broader consideration (Forest et al. 2007).

However, there are sometimes practical reasons to focus conservation efforts on defined populations; for example, the US endangered species act incorporates the idea of evolutionary distinctiveness, based on demonstration of the importance for conserving wild salmon populations (Waples 1991). This can have dramatic impacts for the ability of conservation managers to gain government support for conservation programmes targeting particular focal populations at risk, rather than whole species that might have wider distributions and could help to bridge the gap between scientists and conservation practitioners (Taylor et al. 2017). Nevertheless, concern remains that lack of consensus on species definitions will inhibit conservation efforts (Frankham 2010), with some promoting return to the biological species concept rather than evolutionary based definitions for making conservation management decisions (Ralls et al. 2017) and others asserting that phylogenetic distinctiveness better describes the evolutionary process of speciation (Groves et al. 2017). There is also increasing evidence that hybridisation might represent a creative rather than destructive force in evolution. For example, based on RFLPs, Whitham et al. (1999) found more hybridisation than expected among species of cottonwoods but predicted that introgression was restricted to particular parts of the genome; they also suggested that plant hybrid zones might support a higher diversity of other organisms. Genomic studies have dramatically expanded on such views; signatures of introgression have been found more widely than expected and hybrid speciation even in diploids has been resurrected as a driving force in evolution that could have important conservation implications (e.g. Robinson et al. 2016; vonHoldt et al. 2016, 2017; Quilodran et al. 2018; Smith et al. 2018).

The type of genetic markers used to define units for conservation has also been debated. Original approaches were based on mtDNA variation (Moritz 1994a, b), but the use of genes that could be used as a proxy for adaptation, such as immune genes at the Major Histocompatibility Complex (MHC), have also been promoted for conservation and captive breeding programmes (e.g. Hughes 1991; Aguilar et al. 2004; Luo et al. 2004; Ujvari and Belov 2011; Marsden et al. 2012; Savage et al. 2018). Neutral and selected genes also provide different types of information relevant for predicting adaptive potential and so combined perspectives could be most informative (Funk et al. 2012; Pauls et al. 2013). Pluralistic approaches to defining independently evolving units (e.g. Fennessy et al. 2016) are also preferable to definitions based on single genes but questions about what impacts this might have on small threatened populations and on interpretation of congruence (Bercovitch et al. 2017) and fit to a multispecies coalescent model (Barley et al. 2018) have been questioned. Shifts towards genome-wide Single Nucleotide Polymorphisms (SNPs) will be particularly useful to provide a comprehensive assessment of genetic distinctiveness and will allow more precision in targeting of what deserves special efforts for conservation (Morin et al. 2004; Desalle and Amato 2017). Holistic perspectives that consider genome-wide variation, ecological factors and historical contexts from fossils will also become more practical and in some cases might open new debates about species boundaries (e.g. for wolves: Rutledge et al. 2012; vonHoldt 
et al. 2017). Sampling design also remains a critical issue for interpreting patterns of variation; although the increased power provided by genomic scale data technically allows inferences based on fewer individuals per population than less informative markers, adequate sampling is still critical (e.g. Galapagos tortoises: Gaughran et al. 2017). However, even with increased precision, the question remains about how definition of genetically distinct units should be used most effectively to inform conservation management decisions. Critical to progress will be to develop mechanisms to ensure that genomic developments are translated into practical interventions through effective communication between academic researchers and conservation practitioners (see discussion in Shafer et al. 2015, 2016; Garner et al. 2016).

\section{How much genetic variation is enough?}

An important issue to consider if genetic variation is used as a central criterion to set conservation priorities is how do we determine when appropriate levels of diversity, heterozygosity and connectivity between populations exist and when interventions might be warranted? Simberloff (1988), for example, emphasized that genetics is equivocal about the value of preserving connectivity between refuges; maintaining connectivity promotes gene flow but this might prevent local adaptation to changing environmental conditions or enhance spread of diseases between populations. What constitutes barriers to connectivity also could be misinterpreted; for example, fragment boundaries might not reflect real ecological boundaries for trees that exhibit long-distance pollination or seed dispersal (Kramer et al. 2008). As with original debates about phenetic-based classification systems for naming species (Farris 1977) and more recent discussions about thresholds of divergence to classify a broad range of species based on DNA barcoding (e.g. Hebert et al. 2003; Vences et al. 2005; Mattio and Payri 2010; Schoch et al. 2012), or for interpreting diversity of operational taxonomic units (OTUs) in microbiome studies (Konstantinidis and Tiedje 2005; Goodrich et al. 2014), it is highly unlikely that a single threshold could be set that would apply across a wide range of taxonomic groups. For example, Smith and Donoghue (2008) demonstrated that rates of molecular evolution vary widely among angiosperms and are more related to life history traits than taxonomy. Thus, even within taxonomic groups, setting a single threshold that would describe optimal patterns of variation would be difficult to establish.

It is also difficult to predict how much heterozygosity should be maintained to achieve genetically "healthy" populations. Avise (1989) suggested that relationships between heterozygosity and population viability are complex but also that organisms with different types of mating systems will vary in how much heterozygosity is "normal". For example, despite concerns that low levels of genetic variation and homozygosity in cheetahs reflected genetic erosion due to habitat fragmentation and a historical bottleneck in the Pleistocene (O'Brien et al. 1985, 2017), this has not resulted in higher impacts of disease in wild populations compared to other carnivores (Caro and Laurenson 1994; Thalwitzer et al. 2010; Castro-Prieto et al. 2011). In plants, a shift from outcrossing to inbreeding is one of the most frequent evolutionary transitions (Barrett 2003), with heterozygosity decreasing more rapidly in the few first generations after selfing than genetic diversity (Charlesworth and Charlesworth 1979). Nevertheless, many highly successful invasive plant species are highly inbred or clonal (Barrett et al. 2008). The history of inbreeding or other demographic parameters within a given lineage could thus alter interpretation of when "healthy" levels of genetic variation have been compromised by habitat changes or isolation.

The type of genetic variation also could be more important than how much overall variation is maintained; adaptive significance rather than just phylogenetic distinctiveness could be more relevant for conservation (Crandall et al. 2000; Holderegger et al. 2006). Amos and Balmford (2001) reiterated the common view that habitat fragmentation threatens slow erosion of genetic variability by drift and short-term reductions in fitness due to inbreeding depression, but pointed out that there is also evidence that at least some species appear to have mechanisms to maintain higher than expected levels of variability. They suggested that this could be enhanced, for example, by increased relative fitness of more outcrossed individuals rather than severe inbreeding depression in inbred individuals. Maintenance of variation at adaptively important genes has been found even for species where isolation and inbreeding predict low levels of genetic variation at neutral markers (e.g. Aguilar et al. 2004; Castro-Prieto et al. 2011; Funk et al. 2016; Robinson et al. 2016; Benazzo et al. 2017). Just as for neutral genes, this has led to discussions about the value of quantifying "diversity thresholds" for important adaptive processes; for example, to predict relative susceptibility to disease (King and Lively 2012). Genome-scale perspectives will allow a much more quantitative assessment of what types of genetic variation are most relevant for understanding risks of population declines.

There is also an outstanding question of whether variation should be preserved within isolated populations that show reductions in diversity or in more of a metapopulation framework to maintain diversity over larger geographic regions. For example, Charruau et al. (2011) advocate that conservation strategies should be implemented that can simultaneously facilitate conservation priorities of preserving locally adapted ecotypes and genetic diversity across the range of a species. Such an approach has proven effective, for example, for highly endangered Tasmanian devils, but relied on using 
captively bred individuals rather than just wild populations (Hogg et al. 2017). Developments in forensic approaches to working with ancient DNA also will be useful for establishing a longer time scale over which neutral and adaptive variation can be considered within species, to establish historical information on how much variation is "normal" and to identify the most appropriate source populations to use for reintroductions or translocations (Marr et al. 2018). However, even with more fine-scale information based on genome-wide SNPs, setting thresholds for how much diversity to preserve and over what proportion of the range of a species remains a substantial challenge.

\section{Genetics of adaptation}

Genomic approaches will allow unprecedented opportunities to precisely determine the amount, distribution and functional significance of genetic variation in natural populations across a wide range of organisms (Allendorf et al. 2010; Fuentes-Pardo and Ruzzante 2017). However, in order to be able to use this detailed genetic information as a predictive tool to mitigate the consequences of changing environments, it is important that an eco-evolutionary perspective is maintained, considering both short-term ecological consequences of genetic interventions and long-term evolutionary processes related to adaptation (Keyghobadi 2007; Kinnison and Hairston 2007; Schwartz et al. 2007; Frankham 2010; Ouborg et al. 2010; Eizaguirre and Baltazar-Soares 2014; Shafer et al. 2015). Genetic diversity can affect ecological processes such as primary productivity, population resilience to disturbance, interspecific competition, community composition, and energy and nutrient fluxes at the population, community and ecosystem levels but the relative importance of genetics to other factors is not often assessed (Hughes et al. 2008). A recent meta-analysis of factors that limit animal movements found that the vast majority of studies $(77 \%)$ focused on restrictions to gene flow, and few investigated consequences for restricted demographic exchange (17\%) and limited resource access (10\%) (Cosgrove et al. 2018). There is also increasing evidence that variation in the biotic environment can be critical for determining fitness; for example, community ecology of microbes can have large effects on adaptation (Guo et al. 2018) but understanding interactions with "host" genetics is an open question. Combining "omic" approaches also might reveal new insights into consequences of population bottlenecks beyond reduction in genetic variation; for example, combining genome-wide association studies (GWAS) to identify quantitative trait loci (QTLs) related to adaptive traits that could be tested for evidence of selection or differential expression (through transcriptomics) in different environmental contexts, with metabolomics or proteomics to assess resulting physiological differences. Taking a GWAS approach to investigating changes in metabolomes has been applied to investigate the genetic architecture of secondary metabolites affecting human nutrition in crops (Matsuda et al. 2014), to uncover the functional basis of productionreducing traits in livestock (Welzenbach et al. 2016) and in relation to metabolic costs of human disease (e.g. Adamski 2012) but has not yet been commonly applied in conservation settings. For conservation applications, combining such big data approaches with detailed ecological assessments about limits to adaptation would be particularly powerful to assess relative risks to declining populations.

Advances in analytical approaches also provide more potential to efficiently combine genomic tools with field experiments to test adaptive potential (Savolainen et al. 2013). Reciprocal transplant experiments and common garden experiments are powerful tools for quantifying the relationship between population size and local adaptation (Leimu and Fischer 2008); combined with genomics they provide the potential to robustly assess the relationship between genetic variation and adaptation. Such approaches can also be applied to multiple species inhabiting common environments (Bucharova et al. 2017). For example, even closely related species inhabiting the same environments can show differences in genetic variation and adaptive potential at fine local scales (Lobo et al. 2018), which should be accounted for in multi-species based conservation. Landscape genomics, combining phylogeographic patterns with detailed environmental data (Gugger et al. 2018) also could aid in the restoration and preservation of either particular threatened species or larger communities (Montalvo et al. 1997; Funk et al. 2008), by informing practical decisions about what to preserve, how and over what geographic scales (McKay et al. 2005). Relating genomic variation to critical phenotypic responses to environmental stress (Bustos-Salazar et al. 2017; Vangestel et al. 2018) can be used to inform selection of individuals to use for restoration or breeding programmes for sustainably harvested populations. Combining remote sensing (Turner et al. 2003; Vihervaara et al. 2017) and ecological niche modelling (May et al. 2011; De La Torre et al. 2014) with conservation genetics is also a powerful way to predict future adaptation. Such approaches demonstrate, for example, that land availability could be more important than genetic diversity in range shifts (Broadhurst et al. 2018) and highlight that climate change could also create new habitats, as species expand into climatically previously inaccessible locations (Luoto et al. 2006). However, it is also important to assess whether rapid changes in climate risk overwhelming the capacity for adaptation (Jump and Penuelas 2005). Thus, integrating advances in ecology and geography with genomics will increase potential to establish predictive frameworks for the consequences of conservation management decisions. 
It is also becoming apparent that rapid adaptation can happen in the absence of substantive genetic variation. For example, Willoughby et al. (2018) found that introduced populations of steelhead trout showed very low genomewide diversity compared to their native range but showed signatures of rapid adaptation at several loci related to transition to an anadromous to freshwater restricted lifestyle. The changing views of epigenetics that have come from genomic studies (Jablonka and Lamb 2002) and evidence that differences in phenotypic plasticity could be important for determining species distributions in changing climates (Valladares et al. 2014) or explaining success of invasive species (Parker et al. 2003) suggest that just studying underlying genomic variation will not be sufficient to predict responses to climate change. Managing phenotypes rather than genotypes has been suggested for habitat restoration (Watters et al. 2003) and transcriptome studies using gene expression as a phenotype (DeBiasse and Kelly 2016; Elmer 2016) have revealed important insights into the genomic control of immediate responses to environmental stress. However, such studies have also questioned whether phenotypic plasticity results in long-term adaptation rather than rapid responses to environmental stress (Ho and Zhang 2018). It is also increasingly apparent that local adaptation and adaptive divergence can happen even with high gene flow (Attard et al. 2018; Shih et al. 2018). Advances could also be made in how we compare phenotypic and genotypic variation that go beyond correlations (e.g. Qst vs Fst: McKay and Latta 2002) and more directly test the functional consequences of genetic changes. There is also the chicken and the egg type question of whether genetic variation is caused by local adaptation or whether local adaptation relies on pre-existing genetic variation (Taylor 1991). For example, a recent study on birds found a positive correlation between the magnitude of changes in allele frequencies necessary to keep up with changing climatic conditions and the magnitude of population declines, suggesting that lack of adaptation may already have had a negative effect on genetic variation and adaptive potential (Bay et al. 2018). Similarly, a low level of MHC variation in a vulnerable frog species was concluded to be a consequence rather than the cause of selection for alleles promoting survival in the face of the continual presence of important disease agents (Savage et al. 2018); local adaptation to a prevalent disease threat can actually reduce genetic variation. Focusing on preservation of adaptive phenotypes rather than genotypes could thus be important to consider as we learn more about the regulation of adaptive processes at the genomic level.

We could also learn from successful adaptation examples rather than just firefighting to predict what is limiting adaptation of threatened species. Although the majority of studies on invasive species attempt to determine what can be done to restrict invasiveness (Pagad et al. 2018), using invasive species as models to understand the genomic basis of successful colonization of new environments and resilience to climatic change (Suarez and Tsutsui 2008) has potential for predicting strategies for management of endangered species as well. Since invasive species are often colonising new habitats with a small number of founders, almost by definition they have to be able to adapt to altered environmental conditions without substantial genetic variation (Caron et al. 2014). Investigating the genetic architecture of adaptive traits in the face of this limited variation (Puzey and Vallejo-Marin 2014; Dlugosch et al. 2015) and on the reproductive and phenotypic strategies associated with successful establishment in new environments (Barrett et al. 2008; van Kleunen et al. 2008) could provide important insights for conservation management. Determining the genomic basis for changes in physiological and behavioural traits associated with adaptation could be particularly important.

\section{Conclusions}

The increasing accessibility of genome scale "omics", combined with advances in ecological niche modelling and population genomic analyses hold great promise for developing more functional perspectives about adaptive potential than was possible using previous technologies. However, it is important that we don't use these approaches simply to add more fine-scale details to our catalogue of genetic variation but think about what we can learn about the circumstances in which this variability "matters" for conservation. Arguably, the largest recent advances have been made in understanding the genomic basis of adaptation but the difficult part will be to incorporate this knowledge into active management plans. We also might need to rethink some long-standing perspectives on the relative importance of genetic variation to conservation. Genome-scale analyses question whether our views have been too simplistic: for example, genomic signatures of phenotypic plasticity, epigenetics, hybridisation, and maintenance of adaptive variation despite high inbreeding are all more apparent than previously suspected. The relative fitness consequences of inbreeding versus outbreeding, focus on "species" as the units of conservation, determining how much variation should be the target of genetic interventions, and strategies for genetic rescue and restoration ecology all could be tackled from new perspectives based on combining genome scale "omics" with ecological scale experiments.

Acknowledgements I thank Rus Hoelzel for organising and inviting me to contribute to the workshop on "Conservation of adaptive potential and functional diversity", on which this special issue is based. Thank you to all of the participants for stimulating discussions and intriguing presentations. The comments of two anonymous reviewers substantially improved the manuscript. 
Open Access This article is distributed under the terms of the Creative Commons Attribution 4.0 International License (http://creativeco mmons.org/licenses/by/4.0/), which permits unrestricted use, distribution, and reproduction in any medium, provided you give appropriate credit to the original author(s) and the source, provide a link to the Creative Commons license, and indicate if changes were made.

\section{References}

Adamski J (2012) Genome-wide association studies with metabolomics. Genome Med 4:34-34

Aguilar A, Roemer G, Debenham S, Binns M, Garcelon D, Wayne RK (2004) High MHC diversity maintained by balancing selection in an otherwise genetically monomorphic mammal. PNAS 101:3490-3494

Aguilar R, Quesada M, Ashworth L, Herrerias-Diego Y, Lobo J (2008) Genetic consequences of habitat fragmentation in plant populations: susceptible signals in plant traits and methodological approaches. Mol Ecol 17:5177-5188

Allendorf FW, Hohenlohe PA, Luikart G (2010) Genomics and the future of conservation genetics. Nat Rev Genet 11:697-709

Amos W, Balmford A (2001) When does conservation genetics matter? Heredity, 87, 257-265

Attard CRM, Brauer CJ, Sandoval-Castillo J, Faulks LK, Unmack PJ, Gilligan DM, Beheregaray LB (2018) Ecological disturbance influences adaptive divergence despite high gene flow in golden perch (Macquaria ambigua): implications for management and resilience to climate change. Mol Ecol 27:196-215

Avise JC (1989) A role for molecular genetics in the recognition and conservation of endangered species. Trends Ecol Evol 4:279-281

Barley AJ, Brown JM, Thomson RC (2018) Impact of model violations on the inference of species boundaries under the multispecies coalescent. Syst Biol 67:269-284

Barrett SCH (2003) Mating strategies in flowering plants: the outcrossing-selfing paradigm and beyond. Proc R Soc B 358:991-1004

Barrett SCH, Colautti RI, Eckert CG (2008) Plant reproductive systems and evolution during biological invasion. Mol Ecol 17:373-383

Bay RA, Harrigan RJ, Le Underwood V, Gibbs HL, Smith TB, Ruegg K (2018) Genomic signals of selection predict climate-driven population declines in a migratory bird. Science 359:83-86

Benazzo A, Trucchi E, Cahill JA, Maisano Delser P, Mona S, Fumagalli M, Bunnefeld L, Cornetti L, Ghirotto S, Girardi M, Ometto L, Panziera A, Rota-Stabelli O, Zanetti E, Karamanlidis A, Groff C, Paule L, Gentile L, Vilà C, Vicario S, Boitani L, Orlando L, Fuselli S, Vernesi C, Shapiro B, Ciucci P, Bertorelle G (2017) Survival and divergence in a small group: the extraordinary genomic history of the endangered Apennine brown bear stragglers. PNAS 114:E9589

Bercovitch FB, Berry PSM, Dagg A, Deacon F, Doherty JB, Lee DE, Mineur F, Muller Z, Ogden R, Seymour R, Shorrocks B, Tutchings A (2017) How many species of giraffe are there? Curr Biol 27:R136-R137

Broadhurst LM, Mellick R, Knerr N, Li L, Supple MA (2018) Land availability may be more important than genetic diversity in the range hift response of a widely distributed eucalypt, Eucalyptus melliodora. Forest Ecol Manag 409:38-46

Brommer JE, Kekkonen J, Wikström M (2015) Using heterozygosity-fitness correlations to study inbreeding depression in an isolated population of white-tailed deer founded by few individuals. Ecol Evol 5:357-367

Bucharova A, Michalski S, Hermann JM, Heveling K, Durka W, Holzel N, Kollmann J, Bossdorf O (2017) Genetic differentiation and regional adaptation among seed origins used for grassland restoration: lessons from a multispecies transplant experiment. J Appl Ecol 54:127-136

Buckley J, Holub EB, Koch MA, Vergeer P, Mable BK (2018) Restriction associated DNA-genotyping at multiple spatial scales in Arabidopsis lyrata reveals signatures of pathogenmediated selection. BMC Gen 19:496

Bustos-Salazar A, Smith-Ramirez C, Zuniga-Feest A, Alves F, Ivanovich R (2017) Which seed origin provides better tolerance to flooding and drought when restoring to face climate change? Austral Ecol 42:934-946

Carleial S, van Kleunen M, Stift M (2017) Relatively weak inbreeding depression in selfing but also in outcrossing populations of North American Arabidopsis lyrata. J Evol Biol 30:1994-2004

Caro TM, Laurenson MK (1994) Ecological and genetic factors in conservation: a cautionary tale. Science 263:485-486

Caron V, Ede FJ, Sunnucks P (2014) Unravelling the paradox of loss of genetic variation during invasion: superclones may explain the success of a clonal invader. PLoS ONE, 9, e97744

Castro-Prieto A, Wachter B, Sommer S (2011) Cheetah paradigm revisited: MHC diversity in the world's largest free-ranging population. Mol Biol Evol 28:1455-1468

Charlesworth D, Charlesworth B (1979) The evolution and breakdown of S-allele systems. Heredity 43:41-55

Charlesworth B, Charlesworth D (1999) The genetic basis of inbreeding depression. Genet Res 74:329-340

Charruau P, Fernandes C, Orozco-ter Wengel P, Peters J, Hunter L, Ziaie H, Jourabchian A, Jowkar H, Schaller G, Ostrowski S, Vercammen P, Grange T, Schlotterer C, Kotze A, Geigl EM, Walzer C, Burger PA (2011) Phylogeography, genetic structure and population divergence time of cheetahs in Africa and Asia: evidence for long-term geographic isolates. Mol Ecol 20:706-724

Cosgrove AJ, McWhorter TJ, Maron M (2018) Consequences of impediments to animal movements at different scales: a conceptual framework and review. Divers Distrib 24:448-459

Crandall KA, Bininda-Emonds ORP, Mace GM, Wayne RK (2000) Considering evolutionary processes in evolutionary biology. Trends Ecol Evol 15:290-295

David P (1998) Heterozygosity-fitness correlations: new perspectives on old problems. Heredity 80:531

De La Torre AR, Roberts DR, Aitken SN (2014) Genome-wide admixture and ecological niche modelling reveal the maintenance of species boundaries despite long history of interspecific gene flow. Mol Ecol 23:2046-2059

DeBiasse MB, Kelly MW (2016) Plastic and evolved responses to global change: what can we learn from comparative transcriptomics? J Hered 107:71-81

Desalle R, Amato G (2017) Conservation genetics, precision conservation, and de-extinction. Hast Cent Rep 47:S18-S23

Dlugosch KM, Anderson SR, Braasch J, Cang FA, Gillette HD (2015) The devil is in the details: genetic variation in introduced populations and its contributions to invasion. Mol Ecol 24:2095-2111

Eckert CG, Barrett SCH (1994) Inbreeding depression in partially selffertilizing Decodon verticillatus (Lythraceae): population genetic and experimental analyses. Evolution 48:952-964

Edmands S (1999) Heterosis and outbreeding depression in interpopulation crosses spanning a wide range of divergence. Evolution 53:1757-1768

Eizaguirre C, Baltazar-Soares M (2014) Evolutionary conservationevaluating the adaptive potential of species. Evol Appl 7:963-967

Elmer KR (2016) Genomic tools for new insights to variation, adaptation, and evolution in the salmonid fishes: a perspective for charr. Hydrobiologia 783:191-208

Farris JS (1977) On the phenetic approach to vertebrate classification. In: Hecht MK, Goody PC, Hecht BM (eds) Major patterns in vertebrate evolution. Springer, Boston, pp 823-850 
Fennessy J, Bidon T, Reuss F, Kumar V, Elkan P, Nilsson MA, Vamberger M, Fritz U, Janke A (2016) Multi-locus analyses reveal four giraffe species instead of one. Curr Biol 26:2543-2549

Forest F, Grenyer R, Rouget M, Davies TJ, Cowling RM, Faith DP, Balmford A, Manning JC, Proches S, van der Bank M, Reeves G, Hedderson TAJ, Savolainen V (2007) Preserving the evolutionary potential of floras in biodiversity hotspots. Nature 445:757-760

Fox CW, Reed DH (2011) Inbreeding depression increases with environmental stress: an experimental study and meta-analysis. Evolution 65:246-258

Foxe JP, Stift M, Tedder A, Haudry A, Wright SI, Mable BK (2010) Reconstructing origins of loss of self-incompatibility and selfing in North American Arabidopsis lyrata: a population genetic context. Evolution 64:3495-3510

Frankham R (1995) Inbreeding and extinction-a threshold effect. Conserv Biol 9:792-799

Frankham R (2010) Where are we in conservation genetics and where do we need to go? Conserv Gen 11:661-663

Frankham R (2015) Genetic rescue of small inbred populations: meta-analysis reveals large and consistent benefits of gene flow. Mol Ecol 24:2610-2618

Franklin IR, Frankham R (1998) How large must populations be to retain evolutionary potential? Anim Conserv 1:69-70

Fraser DJ (2017) Genetic diversity of small populations: not always "doom and gloom"? Mol Ecol 26:6499-6501

Fraser DJ, Bernatchez L (2001) Adaptive evolutionary conservation: towards a unified concept for defining conservation units. Mol Ecol 10:2741-2752

Fuentes-Pardo AP, Ruzzante DE (2017) Whole-genome sequencing approaches for conservation biology: advantages, limitations and practical recommendations. Mol Ecol 26:5369-5406

Funk JL, Cleland EE, Suding KN, Zavaleta ES (2008) Restoration through reassembly: plant traits and invasion resistance. Trends Ecol Evol 23:695-703

Funk WC, Mckay JK, Hohenlohe PA, Allendorf FW (2012) Harnessing genomics for delineating conservation units. Trends Ecol Evol 27:489-496

Funk WC, Lovich RE, Hohenlohe PA, Hofman CA, Morrison SA, Sillett TS, Ghalambor CK, Maldonado JE, Rick TC, Day MD, Polato NR, Fitzpatrick SW, Coonan TJ, Crooks KR, Dillon A, Garcelon DK, King JL, Boser CL, Gould N, Andelt WF (2016) Adaptive divergence despite strong genetic drift: genomic analysis of the evolutionary mechanisms causing genetic differentiation in the island fox (Urocyon littoralis). Mol Ecol 25:2176-2194

Garner BA, Hand BK, Amish SJ, Bernatchez L, Foster JT, Miller KM, Morin PA, Narum SR, O’Brien SJ, Roffler G, Templin WD, Sunnucks P, Strait J, Warheit KI, Seamons TR, Wenburg J, Olsen J, Luikart G (2016) Genomics in conservation: case studies and bridging the gap between data and application. Trends Ecol Evol 31:81-83

Gaughran SJ, Quinzin MC, Miller JM, Garrick RC, Edwards DL, Russello MA, Poulakakis N, Ciofi C, Beheregaray LB, Caccone A (2017) Theory, practice, and conservation in the age of genomics: the Galápagos giant tortoise as a case study. Evol Appl 11:1084-1093

Gómez-Sánchez D, Olalde I, Sastre N, Enseñat C, Carrasco R, Marques-Bonet T, Lalueza-Fox C, Leonard JA, Vilà C, Ramírez O (2018) On the path to extinction: inbreeding and admixture in a declining grey wolf population. Mol Ecol 27:3599-3612

Goodrich JK, Di Rienzi SC, Poole AC, Koren O, Walters WA, Caporaso JG, Knight R, Ley RE (2014) Conducting a microbiome study. Cell 158:250-262
Goodwillie C, Kalisz S, Eckert CG (2005) The evolutionary enigma of mixed mating systems in plants: occurrence, theoretical expectations, and empirical evidence. Annu Rev Ecol Syst 36:47-79

Groves CP, Cotterill FPD, Gippoliti S, Robovsky J, Roos C, Taylor PJ, Zinner D (2017) Species definitions and conservation: a review and case studies from African mammals. Conserv Gen 18:1247-1256

Gugger PF, Liang CT, Sork VL, Hodgskiss P, Wright JW (2018) Applying landscape genomic tools to forest management and restoration of Hawaiian koa (Acacia koa) in a changing environment. Evol Appl 11:231-242

Guo W, Mishra S, Zhao JC, Tang JS, Zeng B, Kong FL, Ning RH, Li M, Zhang HZ, Zeng YT, Tian YLZ, Zhong YH, Luo HD, Liu YH, Yang JD, Yang MY, Zhang MW, Li Y, Ni QY, Li CW, Wang CD, Li DS, Zhang HM, Zuo ZL, Li Y (2018) Metagenomic study suggests that the gut microbiota of the giant panda (Ailuropoda melanoleuca) may not be specialized for fiber fermentation. Front Microbiol 9:229

Hebert PDN, Ratnasingham S, deWaard JR (2003) Barcoding animal life: cytochrome $\mathrm{C}$ oxidase subunit 1 divergences among closely related species. Proc R Soc B 270:S96-S99

Hedrick PW (1994) Purging inbreeding depression and the probability of extinction-full-sib mating. Heredity 73:363-372

Hillis DM, Moritz C, Mable BK (1996) Molecular systematics, Second edn. Sinauer, Sunderland

Ho W-C, Zhang J (2018) Evolutionary adaptations to new environments generally reverse plastic phenotypic changes. Nat Commun 9:350

Hogg CJ, Lee AV, Srb C, Hibbard C (2017) Metapopulation management of an endangered species with limited genetic diversity in the presence of disease: the Tasmanian devil Sarcophilus harrisii. Int Zoo Yearbook 51:137-153

Holderegger R, Kamm U, Gugerli F (2006) Adaptive vs. neutral genetic diversity: implications for landscape genetics. Lands Ecol 21:797-807

Hughes AL (1991) MHC polymorphism and the design of captive breeding programs. Conserv Biol 5:249-251

Hughes AR, Inouye BD, Johnson MTJ, Underwood N, Vellend M (2008) Ecological consequences of genetic diversity. Ecol Lett 11:609-623

Jablonka E, Lamb MJ (2002) The changing concept of epigenetics. Ann NY Acad Sci 981:82-96

Jump AS, Penuelas J (2005) Running to stand still: adaptation and the response of plants to rapid climate change. Ecol Lett $8: 1010-1020$

Keller LF, Waller DM (2002) Inbreeding effects in wild populations. Trends Ecol Evol 17:230-241

Keyghobadi N (2007) The genetic implications of habitat fragmentation for animals. Can J Zool 85:1049-1064

King KC, Lively CM (2012) Does genetic diversity limit disease spread in natural host populations? Heredity 109:199-203

Kinnison MT, Hairston NG (2007) Eco-evolutionary conservation biology: contemporary evolution and the dynamics of persistence. Funct Ecol 21:444-454

Konstantinidis KT, Tiedje JM (2005) Genomic insights that advance the species definition for prokaryotes. Proc Natl Acad Sci USA 102:2567

Kramer AT, Ison JL, Ashley MV, Howe HF (2008) The paradox of forest fragmentation genetics. Conserv Biol 22:878-885

Kronenberger JA, Funk WC, Smith JW, Fitzpatrick SW, Angeloni LM, Broder ED, Ruell EW (2017) Testing the demographic effects of divergent immigrants on small populations of Trinidadian guppies. Anim Conserv 20:3-11

Lacy RC (1997) Importance of genetic variation to the viability of mammalian populations. J Mamm 78:320-335 
Lande R (1988) Genetics and demography in biological conservation. Science 241:1455-1460

Leimu R, Fischer M (2008) A meta-analysis of local adaptation in plants. PLoS ONE 3:e4010

Lobo A, Hansen JK, Hansen LN, Kjaer ED (2018) Differences among six woody perennials native to Northern Europe in their level of genetic differentiation and adaptive potential at fine local scale. Ecol Evol 8:2231-2239

Luo SJ, Kim JH, Johnson WE, van der Welt J, Martenson J, Yuhki N, Miquelle DG, Uphyrkina O, Goodrich JM, Quigley HB, Tilson R, Brady G, Martelli P, Subramaniam V, McDougal C, Hean S, Huang SQ, Pan WS, Karanth UK, Sunquist M, Smith JLD, O'Brien SJ (2004) Phylogeography and genetic ancestry of tigers (Panthera tigris). PloS Biol 2:2275-2293

Luoto M, Heikkinen R, Pöyry J, Saarinen K (2006) Determinants of biogeographical distribution of butterflies in boreal regions. J Biogeog 33:1764-1778

Lynch M, O'Hely M (2001) Captive breeding and the genetic fitness of natural populations. Conserv Gen 2:363-378

Marr MM, Brace S, Schreve DC, Barnes I (2018) Identifying source populations for the reintroduction of the Eurasian beaver, Castor fiber L. 1758, into Britain: evidence from ancient DNA. Sci Rep 8:2708

Marsden CD, Woodroffe R, Mills MGL, McNutt JW, Creel S, Groom R, Emmanuel M, Cleaveland S, Kat P, Rasmussen GSA, Ginsberg J, Lines R, Andre JM, Begg C, Wayne RK, Mable BK (2012) Spatial and temporal patterns of neutral and adaptive genetic variation in the endangered African wild dog (Lycaon pictus). Mol Ecol 21:1379-1393

Matsuda F, Nakabayashi R, Yang Z, Okazaki Y, Yonemaru J-i, Ebana K, Yano M, Saito K (2014) Metabolome-genome-wide association study dissects genetic architecture for generating natural variation in rice secondary metabolism. Plant J 81:13-23

Mattio L, Payri C (2010) Assessment of five markers as potential barcodes for identifying Sargassum subgenus Sargassum species (Phaeophyceae, Fucales). Cryptogam Algol 31:467-485

May SE, Medley KA, Johnson SA, Hoffman EA (2011) Combining genetic structure and ecological niche modeling to establish units of conservation: a case study of an imperiled salamander. Biol Conserv 144:1441-1450

McKay JK, Latta RG (2002) Adaptive population divergence: markers, QTL and traits. Trends Ecol Evol 17:285-291

McKay JK, Christian CE, Harrison S, Rice KJ (2005) "How local is local?"- a review of practical and conceptual issues in the genetics of restoration. Restor Ecol 13:432-440

Montalvo AM, Williams SL, Rice KJ, Buchmann SL, Cory C, Handel SN, Nabhan GP, Primack R, Robichaux RH (1997) Restoration biology: a population biology perspective. Restor Ecol 5:277-290

Morin PA, Luikart G, Wayne RK, Grp SW (2004) SNPs in ecology, evolution and conservation. Trends Ecol Evol 19:208-216

Moritz C (1994a) Applications of mitochondrial DNA analysis in conservation: a critical review. Mol Ecol 3:401-411

Moritz C (1994b) Defining 'evolutionary significant units' for conservation. Trends Ecol Evol 9:373-375

Moritz C (1999) Conservation units and translocations: strategies for conserving evolutionary processes. Hereditas 130:217-228

Moritz C (2002) Strategies to protect biological diversity and the evolutionary processes that sustain it. Syst Biol 51:238-254

Mullis KB, Faloona FA (1987) Specific synthesis of DNA in vitro via a polymerase catalyzed chain reaction. Methods Enzymol 155:335-350

Naish KA, Seamons TR, Dauer MB, Hauser L, Quinn TP (2013) Relationship between effective population size, inbreeding and adult fitness-related traits in a steelhead (Oncorhynchus mykiss) population released in the wild. Mol Ecol 22:1295-1309
Newman D, Pilson D (1997) Increased probability of extinction due to decreased genetic effective population size: experimental populations of Clarkia pulchella. Evolution 51:354-362

Nunney L, Campbell KA (1993) Assessing minimum viable population-size-demography meets population genetics. Trends Ecol Evol 8:234-239

O'Brien SJ (1994) A role for molecular genetics in biological conservation. PNAS 91:5748-5755

O’Brien SJ, Evermann JF (1988) Interactive influence of infectious disease and genetic diversity in natural populations. Trends Ecol Evol 3:254-259

O'Brien SJ, Roelke ME, Marker L, Newman A, Winkler CA, Meltzer D, Colly L, Evermann JF, Bush M, Wildt DE (1985) Genetic basis for species vulnerability in the cheetah. Science 227:1428-1434

O'Brien SJ, Johnson WE, Driscoll CA, Dobrynin P, Marker L (2017) Conservation genetics of the cheetah: lessons learned and new opportunities. J Hered 108:671-677

Ouborg NJ, Pertoldi C, Loeschcke V, Bijlsma R, Hedrick PW (2010) Conservation genetics in transition to conservation genomics. Trends Genet 26:177-187

Pagad S, Genovesi P, Carnevali L, Schigel D, McGeoch MA (2018) Data descriptor: introducing the global register of introduced and invasive species. Sci Data 5:170102

Parker IM, Rodriguez J, Loik ME (2003) An evolutionary approach to understanding the biology of invasions: local adaptation and general-purpose genotypes in the weed Verbascum thapsus. Conserv Biol 17:59-72

Pauls SU, Nowak C, Balint M, Pfenninger M (2013) The impact of global climate change on genetic diversity within populations and species. Mol Ecol 22:925-946

Price MV, Waser NM (1979) Pollen dispersal and optimal outcrossing in Delphinium nelsoni. Nature 277:294

Puzey J, Vallejo-Marin M (2014) Genomics of invasion: diversity and selection in introduced populations of monkeyflowers (Mimulus guttatus). Mol Ecol 23:4472-4485

Quilodran CS, Austerlitz F, Currat M, Montoya-Burgos JI (2018) Cryptic biological invasions: a general model of hybridization. Sci Rep 8:2414

Ralls K, Ballou Jonathan D, Templeton A (1988) Estimates of lethal equivalents and the cost of inbreeding in mammals. Conserv Biol 2:185-193

Ralls K, Ballou Jonathan D, Dudash Michele R, Eldridge Mark DB, Fenster Charles B, Lacy Robert C, Sunnucks P, Frankham R (2017) Call for a paradigm shift in the genetic management of fragmented populations. Conserv Lett 11:e12412

Robinson Jacqueline A, Ortega-Del Vecchyo D, Fan Z, Kim Bernard Y, vonHoldt Bridgett M, Marsden Clare D, Lohmueller Kirk E, Wayne Robert K (2016) Genomic flatlining in the Endangered Island fox. Curr Biol 26:1183-1189

Rutledge LY, Wilson PJ, Klütsch CFC, Patterson BR, White BN (2012) Conservation genomics in perspective: a holistic approach to understanding Canis evolution in North America. Biol Conserv 155:186-192

Ryder OA (1986) Species conservation and systematics— the dilemma of subspecies. Trends Ecol Evol 1:9-10

Saiki RK, Gelfand DH, Stoffel S, Scharf SJ, Higuchi R, Horn GT, Mullis KB, Erlich HA (1988) Primer-directed enzymatic amplification of DNA with a thermostable DNA polymerase. Science 239:405-407

Savage AE, Mulder KP, Torres T, Wells S (2018) Lost but not forgotten: MHC genotypes predict overwinter survival despite depauperate MHC diversity in a declining frog. Conserv Gen 19:309-322

Savolainen O, Lascoux M, Merila J (2013) Ecological genomics of local adaptation. Nat Rev Genet 14:807-820 
Schoch CL, Seifert KA, Huhndorf S, Robert V, Spouge JL, Levesque CA, Chen W, Bolchacova E, Voigt K, Crous PW, Miller AN, Wingfield MJ, Aime MC, An KD, Bai FY, Barreto RW, Begerow D, Bergeron MJ, Blackwell M, Boekhout T, Bogale M, Boonyuen N, Burgaz AR, Buyck B, Cai L, Cai Q, Cardinali G, Chaverri P, Coppins BJ, Crespo A, Cubas P, Cummings C, Damm U, de Beer ZW, de Hoog GS, Del-Prado R, Del-Prado R, Dentinger B, Dieguez-Uribeondo J, Divakar PK, Douglas B, Duenas M, Duong TA, Eberhardt U, Edwards JE, Elshahed MS, Fliegerova K, Furtado M, Garcia MA, Ge ZW, Griffith GW, Griffiths K, Groenewald JZ, Groenewald M, Grube M, Gryzenhout M, Guo LD, Hagen F, Hambleton S, Hamelin RC, Hansen K, Harrold P, Heller G, Herrera G, Hirayama K, Hirooka Y, Ho HM, Hoffmann K, Hofstetter V, Hognabba F, Hollingsworth PM, Hong SB, Hosaka K, Houbraken J, Hughes K, Huhtinen S, Hyde KD, James T, Johnson EM, Johnson JE, Johnston PR, Jones EB, Kelly LJ, Kirk PM, Knapp DG, Koljalg U, Kovács GM, Kurtzman CP, Landvik S, Leavitt SD, Liggenstoffer AS, Liimatainen K, Lombard L, Luangsa-Ard JJ, Lumbsch HT, Maganti H, Maharachchikumbura SS, Martin MP, May TW, McTaggart AR, Methven AS, Meyer W, Moncalvo JM, Mongkolsamrit S, Nagy LG, Nilsson RH, Niskanen T, Nyilasi I, Okada G, Okane I, Olariaga I, Otte J, Papp T, Park D, Petkovits T, Pino-Bodas R, Quaedvlieg W, Raja HA, Redecker D, Rintoul T, Ruibal C, Sarmiento-Ramirez JM, Schmitt I, Schussler A, Shearer C, Sotome K, Stefani FO, Stenroos S, Stielow B, Stockinger H, Suetrong S, Suh SO, Sung GH, Suzuki M, Tanaka K, Tedersoo L, Telleria MT, Tretter $\mathrm{E}$, Untereiner WA, Urbina H, Vagvolgyi C, Vialle A, Vu TD, Walther G, Wang QM, Wang Y, Weir BS, Weiss M, White MM, Xu J, Yahr R, Yang ZL, Yurkov A, Zamora JC, Zhang N, Zhuang WY, Schindel D, Consortium FB (2012) Nuclear ribosomal internal transcribed spacer (ITS) region as a universal DNA barcode marker for Fungi. Proc Natl Acad Sci USA 109:6241-6246

Schou MF, Loeschcke V, Bechsgaard J, Schlotterer C, Kristensen TN (2017) Unexpected high genetic diversity in small populations suggests maintenance by associative overdominance. Mol Ecol 26:6510-6523

Schwartz MK, Luikart G, Waples RS (2007) Genetic monitoring as a promising tool for conservation and management. Trends Ecol Evol 22:25-33

Shafer ABA, Wolf JBW, Alves PC, Bergström L, Bruford MW, Brännström I, Colling G, Dalén L, De Meester L, Ekblom R, Fawcett KD, Fior S, Hajibabaei M, Hill JA, Hoezel AR, Höglund J, Jensen EL, Krause J, Kristensen TN, Krützen M, McKay JK, Norman AJ, Ogden R, Österling EM, Ouborg NJ, Piccolo J, Popović D, Primmer CR, Reed FA, Roumet M, Salmona J, Schenekar T, Schwartz MK, Segelbacher G, Senn H, Thaulow J, Valtonen M, Veale A, Vergeer P, Vijay N, Vilà C, Weissensteiner M, Wennerström L, Wheat CW, Zieliński P (2015) Genomics and the challenging translation into conservation practice. Trends Ecol Evol 30:78-87

Shafer ABA, Wolf JBW, Alves PC, Bergström L, Colling G, Dalén L, De Meester L, Ekblom R, Fior S, Hajibabaei M, Hoezel AR, Hoglund J, Jensen EL, Krützen M, Norman AJ, Österling EM, Ouborg NJ, Piccolo J, Primmer CR, Reed FA, Roumet M, Salmona J, Schwartz MK, Segelbacher G, Thaulow J, Valtonen $\mathrm{M}$, Vergeer $\mathrm{P}$, Weissensteiner $\mathrm{M}$, Wheat $\mathrm{CW}$, Vilà $\mathrm{C}$, Zieliński P (2016) Reply to Garner et al. Trends Ecol Evol 31:83-84

Shih KM, Chang CT, Chung JD, Chiang YC, Hwang SY (2018) Adaptive genetic divergence despite significant isolationby-distance in populations of Taiwan cow-tail fir (Keteleeria davidiana var. formosana). Front Plant Sci 9:92

Simberloff D (1988) The contribution of population and community biology to conservation science. Ann Rev Ecol Syst 19:473-511
Smith SA, Donoghue MJ (2008) Rates of molecular evolution are linked to life history in flowering plants. Science 322:86-89

Smith SL, Senn HV, Perez-Espona S, Wyman MT, Heap E, Pemberton JM (2018) Introgression of exotic Cervus (nippon and canadensis) into red deer (Cervus elaphus) populations in Scotland and the English Lake District. Ecol Evol 8:2122-2134

Steiner CC, Putnam AS, Hoeck PEA, Ryder OA (2013) Conservation genomics of threatened animal species. Ann Rev Animal Biosci $1: 261-281$

Stift M, Hunter BD, Shaw B, Adam A, Hoebe PN, Mable BK (2013) Inbreeding depression in self-incompatible North-American Arabidopsis lyrata: disentangling genomic and $S$-locus-specific genetic load. Heredity 110:19-28

Storfer A (1999) Gene flow and endangered species translocations: a topic revisited. Biol Conserv 87:173-180

Suarez AV, Tsutsui ND (2008) The evolutionary consequences of biological invasions. Mol Ecol 17:351-360

Taylor EB (1991) A review of local adaptation in Salmonidae, with particular reference to Pacific and Atlantic salmon. Aquaculture 98:185-207

Taylor HR, Dussex N, van Heezik Y (2017) Bridging the conservation genetics gap by identifying barriers to implementation for conservation practitioners. Glob Ecol Conserv 10:231-242

Templeton AR (1986) Coadaptation and outbreeding depression. In: Soule ME (ed) Conservation bology the science of scarcity and diversity. Sinauer Associates, Sunderland, pp 105-116

Thalwitzer S, Wachter B, Robert N, Wibbelt G, Muller T, Lonzer J, Meli ML, Bay G, Hofer H, Lutz H (2010) Seroprevalences to viral pathogens in free-ranging and captive cheetahs (Acinonyx jubatus) on Namibian farmland. Clin Vaccine Immunol 17:232-238

Turner W, Spector S, Gardiner N, Fladeland M, Sterling E, Steininger M (2003) Remote sensing for biodiversity science and conservation. Trends Ecol Evol 18:306-314

Ujvari B, Belov K (2011) Major histocompatibility complex (MHC) markers in conservation biology. Int J Mol Sci 12:5168-5186

Valladares F, Matesanz S, Guilhaumon F, Araujo MB, Balaguer L, Benito-Garzon M, Cornwell W, Gianoli E, van Kleunen M, Naya DE, Nicotra AB, Poorter H, Zavala MA (2014) The effects of phenotypic plasticity and local adaptation on forecasts of species range shifts under climate change. Ecol Lett 17:1351-1364

van Kleunen M, Manning JC, Pasqualetto V, Johnson SD (2008) Phylogenetically independent associations between autonomous self-fertilization and plant invasiveness. Am Nat 171:195-201

Vangestel C, Eckert AJ, Wegrzyn JL, St Clair JB, Neale DB (2018) Linking phenotype, genotype and environment to unravel genetic components underlying cold hardiness in coastal Douglas-fir (Pseudotsuga menziesii var. menziesii). Tree Genet Genome 14:10

Vences M, Thomas M, Bonett RM, Vieites DR (2005) Deciphering amphibian diversity through DNA barcoding: chances and challenges. Phil Trans R Soc B 360:1859-1868

Vihervaara P, Auvinen AP, Mononen L, Torma M, Ahlroth P, Anttila S, Bottcher K, Forsius M, Heino J, Heliola J, Koskelainen M, Kuussaari M, Meissner K, Ojala O, Tuominen S, Viitasalo M, Virkkala R (2017) How essential biodiversity variables and remote sensing can help national biodiversity monitoring. Glob Ecol Conserv 10:43-59

Vogler AP, DeSalle R (1994) Diagnosing units of conservation management. Conserv Biol 8:354-363

vonHoldt BM, Cahill JA, Fan ZX, Gronau I, Robinson J, Pollinger JP, Shapiro B, Wall J, Wayne RK (2016) Whole-genome sequence analysis shows that two endemic species of North American wolf are admixtures of the coyote and gray wolf. Sci Adv 2:e1501714 
vonHoldt BM, Brzeski KE, Wilcove DS, Rutledge LY (2017) Redefining the role of admixture and genomics in species conservation. Conserv Lett 11:e12371

Waples RS (1991) Pacific salmon, Oncorhynchus spp., and the definition of "species" under the endangered species act. Marine Fish Rev 53:11-22

Watters JV, Lema SC, Nevitt GA (2003) Phenotype management: a new approach to habitat restoration. Biol Conserv 112:435-445

Weeks AR, Sgro CM, Young AG, Frankham R, Mitchell NJ, Miller KA, Byrne M, Coates DJ, Eldridge MDB, Sunnucks P, Breed MF, James EA, Hoffmann AA (2011) Assessing the benefits and risks of translocations in changing environments: a genetic perspective. Evol Appl 4:709-725

Welzenbach J, Neuhoff C, Heidt H, Cinar MU, Looft C, Schellander $\mathrm{K}$, Tholen E, Große-Brinkhaus C (2016) Integrative analysis of metabolomic, proteomic and genomic data to reveal functional pathways and candidate genes for drip loss in pigs. Int J Mol Sci 17:1426

Whitham TG, Martinsen GD, Floate KD, Dungey HS, Potts BM, Keim P (1999) Plant hybrid zones affect biodiversity: tools for a genetic-based understanding of community structure. Ecology $80: 416-428$

Willi Y, Van Buskirk J, Hoffmann AA (2006) Limits to the adaptive potential of small populations. Ann Rev Ecol Evol Syst $37: 433-458$

Willoughby JR, Harder AM, Tennessen JA, Scribner KT, Christie MR (2018) Rapid genetic adaptation to a novel environment despite a genome-wide reduction in genetic diversity. Mol Ecol 27:4041-4051

Wood JLA, Yates MC, Fraser DJ (2016) Are heritability and selection related to population size in nature? Meta-analysis and conservation implications. Evol Appl 9:640-657 